УДК: 711.523:904, 719

ББК: 85.110

A43

DOI: $10.18688 / \mathrm{aa} 200-1-6$

A. Loukaki

\title{
Athens and Rome Contrasted: The Present Challenge of Managing Two Manners of Classicism
}

\section{Managing the past: Between the prosaic and the sublime}

Athens and Rome are the two preeminent classical cities globally ${ }^{1}$. Their heritages, universal canons, have been steady sources of Western, national, and collective memory, inspiration ${ }^{2}$, aesthetics and myth for centuries now. Astonishingly, very little, if anything at all, was comparatively written on the management of their central archaeological domains before a recent publication of this author which informs the analysis here [18]. Therefore, the main contribution of the present article is the original comparison of the classicism of Athens and Rome, seen from an aesthetic and urban design point of view, with emphasis on the physical, metaphysical, urban design, aesthetic and moral aspects of the management of their central archaeological loci, in conjunction with the differences between classical Greek and Roman classicism. The Sacred Rock of the Athenian Acropolis (Fig. 1, Fig. 2), as it is fondly called by the Greeks, is the epitome of democracy, classical beauty, urban constitution, and national struggles for the establishment of the Greek State. The Roman Forum (Fig. 3), together with the adjacent Colosseum, represents imperial power, structural prowess and prominent urbanism. Enduring through tests of time, iconic classical ruins stage modern urban action, real and symbolic; recapitulate cities as syntactic urban permanences, thereby constantly launching issues of monumentality prioritization; trigger new creativity and loom in struggles over civic and national representation.

The $18^{\text {th }}$-century wars of taste like the clash between Giambattista Piranesi and Johann Joachim Winckelmann over the predominance of classical Athens or Rome ${ }^{4}$ possibly reflected

$1 \quad$ Many thanks are due to professors Erik Swyngedouw and David Harvey who read and commented on a previous version of this paper. Also, to engaging participants in a lecture at the Facoltà di Architettura, Sapienza University of Rome, May 2018, and a presentation at the conference Actual Problems of Theory and History of Art VIII in Moscow, October 2018. I was supported financially by the Hellenic Open University (HOU) and the Erasmus+ Program in the former instance, and, in the latter, also supported financially by HOU, as well as hosted graciously and generously, as were all participants, by the organizers of the aforementioned biannual conference. In 2018, they were Lomonosov State University and the State Tretyakov Gallery. Dr. Ekaterina Staniukovich-Denisova was extremely competent and kind throughout our collaboration, in the context of her editorial duties.

${ }_{2}$ See, for instance, the case of sculptor Auguste Rodin in https://www.spectator.co.uk/2018/04/howrodin-made-a-parthenon-above-paris/. Rodin tried to create his own Parthenon in his home at Meudon, Paris. 3 This is an important issue to urban planners and heritage managers alike [16]. My recent research indicates that monuments' prioritization, in the case of Greece, is more complex than the usual classification whereby Greek classical monuments come first, followed by Hellenistic, Roman, Byzantine, and later monuments [20].

4 Winckelmann, the first art historian to make the distinction between Greek, Greco-Roman, and 
the Church plans to secure Rome as the art capital of Europe. Following the "fever for marble," classical ruins -involuntarily on the part of the classical lands whence they came, for a number of reasons, see Loukaki (2008/2016) - supplied museum collections with architectural members and statues. Typical examples include the Parthenon marbles - just heed the ongoing debate on the return of precious cultural treasures such as them - and Apollo at Bassae in the British Museum, or the Aphaia temple statues in the Glyptothek of Munich. These moves matched with advances like historicism, art history, and spatial incorporation of real or replica ruins. Architecture, painting, sculpture, urban planning, psychology and literature followed suit. Aesthetic attitudes and theory sustaining neoclassicism included dimensions of harmony, clarity, restraint, universality and idealism ${ }^{5}$. Architects like Schinkel and Soane, painters like Ingres

Roman art, supported the achievement of Greek architecture. Piranesi was a leading advocate for the preeminence of Roman architecture. In Della Magnificenza ed Architettura de Romani (1761), he included a sequence of illustrations depicting Roman invention. See Winckelmann, the first art historian to make the distinction between Greek, Greco-Roman, and Roman art, supported the achievement of Greek architecture. Piranesi was a leading advocate for the preeminence of Roman architecture. In Della Magnificenza ed Architettura de Romani (1761), he included a sequence of illustrations depicting Roman inventions. See http://omeka.wellesley.edu/ piranesi-rome/exhibits/show/giovanni-battistapiranesi/della-magnificenza. Pope Urban VIII, elected in 1623, was determined to maintain the position of Rome as the artistic capital of Europe, and artists from around the world gathered there to materialize this will. Source: Wikipedia. See also [1, p. 17].

Source: Britannica.

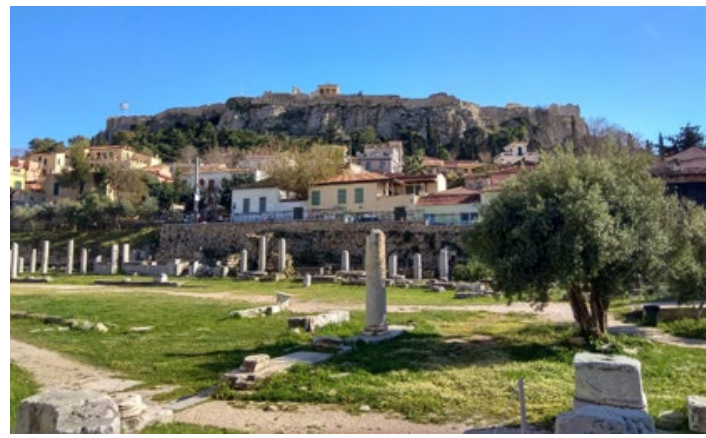

Fig. 1. The northern slope of the Sacred Rock of the Athenian Acropolis, overlooking the Roman Agora and the neoclassical neighborhood of Plaka.

Photo and (C) by A. Loukaki

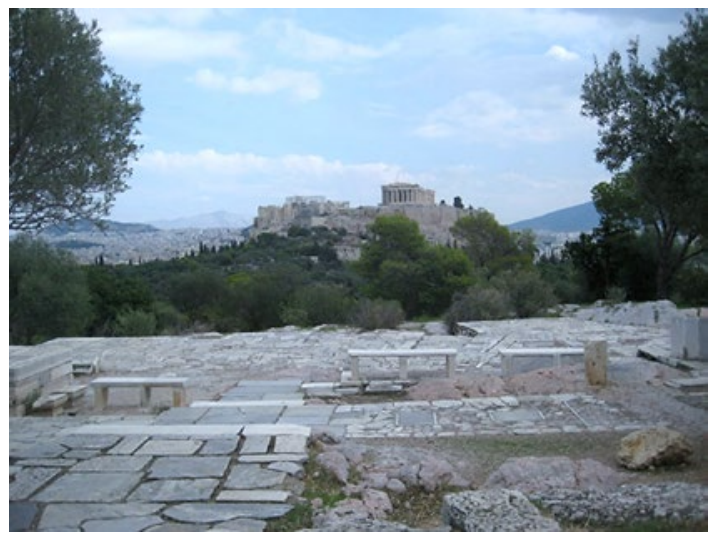

Fig. 2. The Acropolis western side seen from the main plateau on Philopappos Hill designed by Greek architect Dimitris Pikionis. Photo and (C) by A. Loukaki

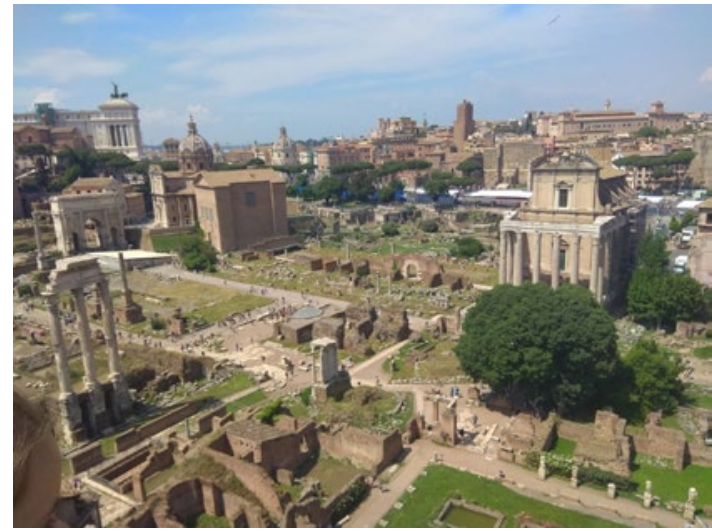

Fig. 3. Rome, the Roman Forum. Photo and (C) by A. Loukaki 
and David, sculptors like Canova and Thorvaldsen ${ }^{6}$, philosophers like Hegel ${ }^{7}$ and Benjamin ${ }^{8}$, authors like Goethe and Henry James, psychoanalysts like Freud and Jung share association with classicism. Modernism also realized, and tried to surpass, classicism's overwhelming potential ${ }^{9}$, while simultaneously being inspired by it.

Safeguarding classical treasures is pursued since the founding of the Greek state in 1830 and the Italian state in 1870. Besides sublime theory, practical logos, what the sociologist Pierre Bourdieu called "le sens pratique," is relevant to

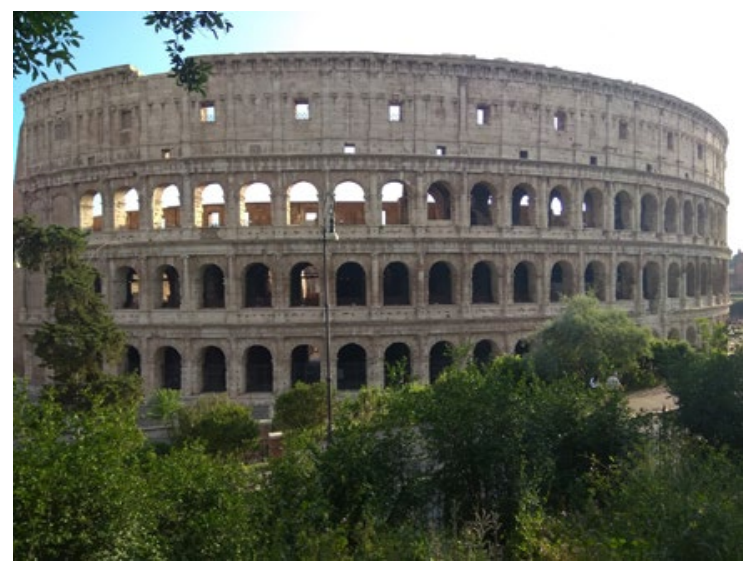

Fig. 4. The Colosseum from the Oppian Hill.

Photo and ( $($ by A. Loukaki heritage-related issues like restoration and adherence to international regulations such as the Venice Charter. Restoration as both theory and praxis, like grand philosophical and aesthetic discourses, is of European genealogy. To French, English, German, and Italian schools of thought, the Greek was added more recently, following acclaimed restorations, such as that of the Acropolis, using modern technologies plus fine handiwork and stricter principles like the reversibility of intervention, expansion and dissemination of expert knowledge, thorough expertise in documentation, and articulation of more in-depth restoration and aesthetic concepts, among others [16].

\section{Roman and Athenian classicism: Likenesses and differences}

Similarities between the two cities include Mediterraneity - a shared geographical location in the Mediterranean and the European South - classical styles, marble sculpture and monuments (though Rome is also rich in brick and concrete classical monuments, see below), plunder of their antiquities, reuse of ancient materials, appropriation of classicism's meanings and symbols, imitation of classical forms, new functions and interpretations. Differences, portrayed in travelogues, include magnitude, as imperial Rome was ten times bigger than classical Athens,

\footnotetext{
$6 \quad$ Many of Thorvaldsen's most characteristic sculptures are new interpretations of figures or themes that were popular in classical antiquity, see http://www.visual-arts-cork.com/sculpture/bertel-thorvaldsen.htm $7 \quad$ However, it was acknowledged that something was "lost in translation." Hegel stressed the expressive fluidity of the Greek sensuous idiom as a linguistic quality lost to modernity. The cultivation of Greek taste, he claimed, had the advantage of resting on the immanent harmony of sichtbare und sichtilche Natur. (Greeks') descriptions of both visual and ethical nature are out of sensuous grounds, livelier and easier to grasp than modern poetry [8].

8 An early sketch suggests "the Arcades" is something like Benjamin's autobiographical work, A Berlin Childhood. "One knew of places in ancient Greece where the way led down into the underworld. Our waking existence likewise is a land which, at certain hidden points, leads down into the underworld - a land full of inconspicuous places from which dreams arise. All day long, suspecting nothing, we pass them by, but no sooner has sleep come than we are groping our way back to lose ourselves in the dark corridors. By day, the labyrinth of urban dwelling resembles consciousness; the arcades... issue unremarked on to the streets. At night, however, under the tenebrous mass of the houses, their denser darkness protrudes like a threat" [4]. This subterranean atmosphere of labyrinths, underworlds and hidden points hints at the workings of the spatial unconscious [17]. $9 \quad$ See respectively Freud and Jung on the one hand, and Malevich on the other. For the latter, see [2, p. 41].
} 
natural topography, and light ${ }^{10}$. Though the quality of light in the two cities intrigues many authors ${ }^{11}$ and architectural historians, all of them have been preceded by Euripides, who praised the bluest sky of Athens in Medea (verses 829-830). Among the most important differences is the disparate local appreciation of classicism. In modern Athens, classicism and neoclassicism have affected the city layout plus building height regulations. But popular involvement supersedes formal channels. Take the Parthenon (Fig. 2): deeply embedded in modern Greek society, the great temple is adulated in ways converging persistent popular and multifarious scholarly elements ${ }^{12}$.

Conversely, modern Rome maintains an ambiguous relation with its classical self. For instance, the Colosseum (Figs. 4, 5) stirs admiration to visitors like Lord Byron (in Childe Harold's Pilgrimage) or Charles Dickens, but also awe and

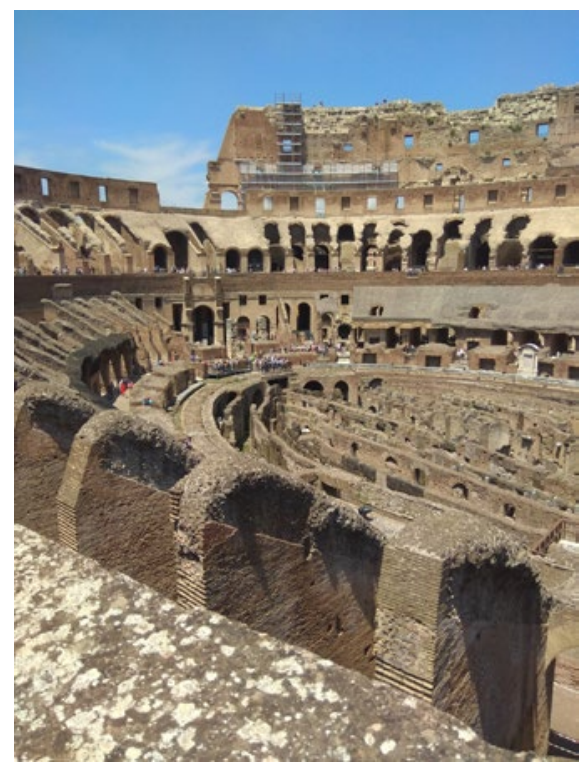

Fig. 5. Interior of the Colosseum.

Photo and (C) by A. Loukaki terror $^{13}$, spurring the uncanny, the unhomely and

10 New Rome acquired global authority from being the seat of papacy [12, pp. 103-104].

11 It was mild midwinter, the season peculiarly of colour on the Roman Campagna; and the light was full of that mellow purple glow, that tempered intensity, which haunts the after-visions of those who have known Rome like the memory of some supremely irresponsible pleasure...The country rolled away around me into slopes and dells of long-drawn grace, chequered with purple and blue and blooming brown. The lights and shadows were at play on the Sabine Mountains - an alternation of tones so exquisite as to be conveyed only by some fantastic comparison to sapphire and amber. It was so bright and yet so sad, so still and yet so charged, to the supersensuous ear, with the murmur of an extinguished life, that you could only say it was intensely and adorably strange. See James in:http://www.online-literature.com/henry_james/italianhours/10/. Sicilian light is more golden and less blinding [28, p. 67].

12 There is evidence from the press and literature $[15 ; 16]$. Scholarly and popular elements are shared by Greeks and foreigners as can be seen, for instance, in the way Jean Cocteau saw the Acropolis [22, p. 275]. 13 The Colosseum would be a terrible shell to Greeks prior to Roman occupation, as their civilization rejected the 'theatricality' of bloody spectacles and of disrespect for the human body. The responding Greek spatiality was classical theater, seat to collective freedom and dignity [17]. Lord Byron, lost in meditation next to the Colosseum, spoke of the human condition [30]. His account in Childe Harold's Pilgrimage depicts architectural triumph, political and military supremacy, but also bloodstreams as spectacle in a locus where life and death became "the playthings of a crowd."

But here; where Murder breathed her bloody steam;

And here, where buzzing nations choked the ways

And roar'd or murmur'd like a mountain stream

Dashing or winding as its torrent strays;

Here, where the Roman million's blame or praise

Was death or life, the playthings of a crowd,

My voice sounds much - and fall the starts' faint rays

On the arena void - seats crush'd - walls bow'd -

And galleries, where my steps seem echoes strangely loud.

The Colosseum, to Dickens was 'the panorama of butchery and persecutions' [6, p. 40]. 


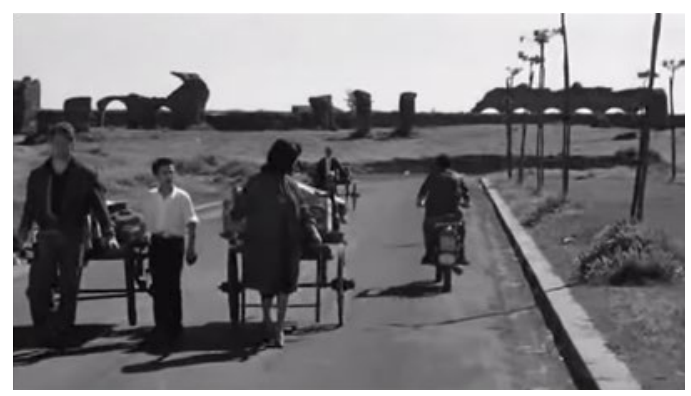

Fig. 6. A scene from Pasolini's Mama Roma (1962), elaborated by the author. The Claudian Aqueduct is visible as a background

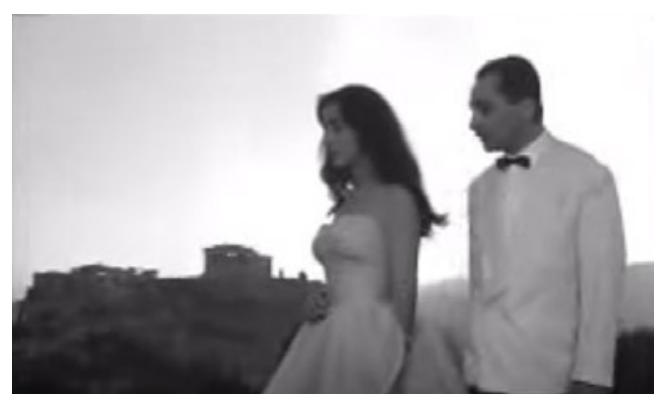

Fig. 7. A scene from Cacoyannis'A Matter of Dignity (1958), elaborated by the author. The Acropolis is the background of action

scary as an urban aesthetic category. The uncanny is closely related, I would propose, to how Roman ruins age. Holed, of indented fragmentation, brick-faced concrete ruins may appear as gloomily melting masses. Conversely, finely elaborated marble ruins remain geometrically crisp and noble, simple and vital transmitters of light, propelling aesthetic and spiritual elation. Romans themselves perceived the aesthetic qualities of marble since magnificence was vitally important to Latin culture as a reflection of republican values. Vitruvius claimed that public architecture had to be useful, beautiful and magnificent [18]. Perhaps this, in conjunction with the difference in natural light, is partly the reason why authors like Henry James or Jean Cocteau described Rome as 'heavy' and Athens as 'light'. A further difference can be located in the fact that the Roman Forum was highly manipulated and physically transformed by Fascism (see below).

This disquiet is captured in both painting, including the many painting representations of the Colosseum, such as Piranesi's, and in film. Fellini's La Dolce Vita uses the past as an ironic counterpoint to frivolous 1960s parties of the Roman affluent class. The archetypal Claudian Aqueduct [30] in Pier Paolo Pasolini's Mamma Roma (1962) (Fig. 6) is a commentary of dystopia and death in Rome's expanding urban sprawl of that time. Frustrated inferiority but also immense admiration towards the past pervade, more recently, Paolo Sorrentino's La Grande Bellezza (2013).

The depiction of Athenian antiquities is more nuanced. In Michalis Cacoyannis' A Matter of Dignity (1958) (Fig. 7) a sunrise over the Acropolis contrasts with personal moral dilemmas, while offering rays of hope ${ }^{14}$. But in Alekos Alexandrakis' Dream Neighborhood (1963), the classical Athenian landscape epitomizes, and is the visual backdrop, of solidarity among the underprivileged inhabitants of this ironically called "dream neighborhood," now extinct.

\section{The Acropolis as heart and culmination of Athens}

The Acropolis (Fig. 1, Fig. 2), the summation and core of Athens since deepest antiquity, is a commanding natural bastion. Counterbalanced by the conic Lycabettus Hill and visually projecting against Mount Hymettus, the Acropolis overlooks the Saronic Gulf and Islands, plus the Peloponnese[5]. National and global renown is partly related to a deep feeling of elation emanating here. 
The question where this feeling comes from is related to the extraordinary spatialities generated by the Acropolis, shaped in the following ways:

Classical forms appear animated by ingenuous response to both the Attic light and the setting.

The Parthenon is a stone vessel, rooted in the Sacred Rock, yet floating towards the sea, alive with human freedom and dignity. Le Corbusier described it thus [13, p. 73]: "when a work is at its maximum intensity, proportions, quality of execution and perfection, it produces the phenomenon of unutterable space, as it starts to actually radiate". This peak moment of the human experience introduces an extraordinary idea of space as a persistent civilizing process; space here becomes humanizing energy.

Neighboring artifacts which facilitated political life (boule, ecclesia, Areopagus, the Pnyx, the Agora ${ }^{15}$ ) and tended to social needs (gymnasium, theater, stadium, odeon) ${ }^{16}$ brace this participatory, civilizing idea of space.

Further, because city and country constituted the polis, namely the city-state, bonds between nature and culture were galvanized together.

\section{The Athens management through the Greek archaeological context}

Greek archaeological management has undertaken the eternal safeguarding of this peak moment of humanity as responsibility of the state to respond to internal and external expectations. The first archaeological law (1834) declared antiquities the national property of all Greeks. Innovations have abounded, including the last law of 2002 (3028/2002).

In regard to the Acropolis, five interrelated sets of issues are, or were, addressed [16]:

First, the excellent and long restoration of the monuments on its top.

Second, the treatment of the $19^{\text {th }}$-century Plaka neighborhood on the northern slope of the Acropolis (Fig. 1).

Third, the archaeological landscaping by architect Pikionis (to which I will return below).

Fourth, the challenge to define the site and architectural style of the New Acropolis Museum, finally inaugurated in 2009.

Fifth, the ongoing restorations on the southern slope of the Acropolis.

\section{Rome's ancient core}

Rome's ancient center ${ }^{17}$, initially a marshy valley surrounded by seven wooded hills ${ }^{18}$, includes the Forum, the Palatine and Capitoline hills plus the Colosseum (Fig. 3). As the symbol of imperial magnificence and the epicenter of social, political, religious and economic life, the

\footnotetext{
15

In Roman times a new Agora was constructed to the east of the Ancient Agora. Hadrian initiated a substantial building program since he sought to make Athens the cultural capital of the Empire and supervised the construction of 'his' Athens, including completion of the Olympian Zeus Temple which stood unfinished for long centuries [31].

16 Poete also differentiated the Greek city from Egypt and the Euphrates, examples of obscure, undeveloped infancy [32, p. 134].

17 A place of "idle elegance and grace" in Henry James's Italian Hours, accessible at http://www.onlineliterature.com/henry_james/italian-hours/10/.

18 The seven hills are still noticeable in today's topography, even though none exceeds 51 meters. Aeneas described the sight thus: "... and they saw herds of cattle lowing here and there in the Roman forum and in the elegant Carinae quarter" [27].
} 
ancient center is an open museum bespeaking determination, structural audacity, large scale and imperial resources ${ }^{19}$. Foundational rites, myths and urban memory were imperative [34]. Military conquests were commemorated through triumphal arches and columns, unlike in Athen $s^{20}$. The importance of urban memory and forgetfulness to the urban constitution of Rome as well are vital: later emperors tried to erase Nero's abominations through damnatio memorieae in order to re-establish urban sanctity.

Unlike the Acropolis, the Forum, more important as a whole than its isolated monuments, is an "urban artifact of extraordinary modernity" that not only summarizes the ancient city [31, p. 119], but also announces modern urbanism ${ }^{21}$ through adaptable transformation. Urban stratigraphy merges coexisting styles, opulence, horror and a Faustian urge for gigantism.

Nonetheless, theoreticians like Rossi ultimately locate Western fundamentals of urban beauty and constitution in Athens [31]. Quite possibly, this is the summation of a great number of parameters, some of which are first perceived through the senses: The latter include an awareness of greatness and deep rootedness but in conjunction with lightness and crispness, a perfect response to the surrounding mountainous, aquatic and luminous landscape, plus the value vested in human dignity transpiring from the Acropolis and its vicinity. It is, perhaps, to do with Hegel's belief in the immanent harmony of the Greek sichtbare und sichtilche Natur, at once visual, ethical and sensuous, or Schiller's "full humanity of the Greeks" [8; 19, and note 7 here].

\section{Rome's management through the Italian archaeological mechanism}

Popes were instrumental towards possessing the ancient glory ${ }^{22}$, which attracted young European aristocrats, as Italy was part of the Grand Tour. The modern city center was created through clearances ${ }^{23}$. The Colosseum was linked to the Lateran, and the Capitoline hilltop was rebuilt by Michelangelo ${ }^{24}$.

From 1870 onwards, Rome was recast as both capital and imperial city through Italianità, the search for national identity and civic pride, becoming home to speculative urbanism ${ }^{25}$. The monument to King Vittorio Emanuele II (1885-1911) in Piazza Venezia (partly visible in the left top side of Fig. 3) rose on ancient urban fabric. Generalized demolitions took place between $1870-1950^{26}$ without documentation [30].

Mussolini intensified the cultural strategy to associate modern Rome, Roma Capitale, and identity, Romanità, with the Roman Empire. The archaeological landscape suffered irreparable wounds by

19 In antiquity, the Capitoline, the most sacred location of the city, was associated with the fortune of Rome through the legend of the colossal head that was discovered there, seen as an omen of future greatness [24]. 20 http://history-world.org/rome.htm. The Forum invited Romans to identify themselves with their city in the powerful way that important urban artifacts do.

${ }_{21}$ The Forum's irregularity was criticized by Livy [27, p. 119]. Around the $5^{\text {th }}$ century, the Forum ceased its activities as marketplace and became the center of Rome and a true meeting place until the fall of the Empire [1].

22 Rome was restored after the papacy returned to the city in 1420 , thereafter becoming the engine of the urban transformation until the $19^{\text {th }}$ century.

${ }_{23}$ Including those around the Antonine column and the Piazza Colonna [27, p. 125].

24 Marcus Aurelius' ancient Roman equestrian statue was placed in the Piazza del Campidoglio (Capitoline Hill) following Michelangelo's redesign of the hilltop.

$25 \quad$ Excavation in the Colosseum began in $1874[9$, p. 112].

26 After the Barbarians of the $3^{\text {rd }}$ century AD and the mercenaries of Charles $\mathrm{V}$ in 1527 , the city succumbed to ravaging. 
Mussolini. Harboring grand dreams for a 20-million city, the Duce campaigned against the Papacy and localism, imitated previous cultural practices to propel his historical conception [11] and dissected the Forum, removing one of the seven hills, the Velian ${ }^{27}$, to construct the Via dei Fori Imperiali linking Piazza Venezia with the Colosseum. This heavily trafficked road, lined with emperors' statues, was used as visual propaganda to instill in Italians pride, power, and discipline [1, pp. 47-48) (Fig. 8).

Archaeologists and restorers like Gustavo Giovanonni did not generally

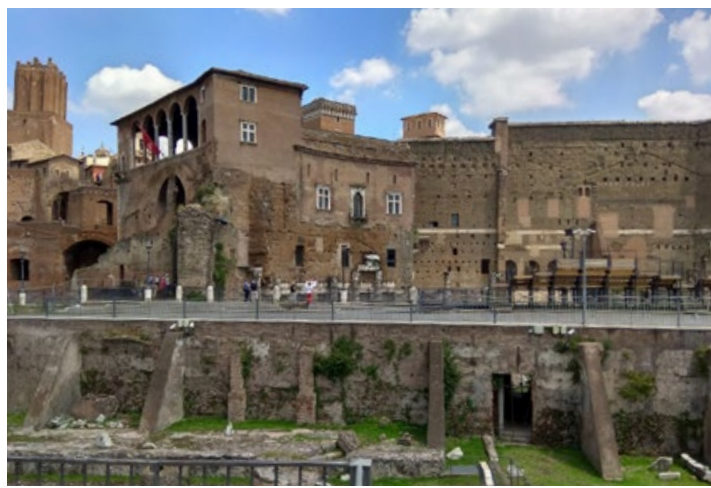

Fig. 8. Via dei Fori Imperiali. The dissection of the Forum by Mussolini through the construction of this sacrilegious Via is visible here. Photo and (C) by A. Loukaki resist destruction, though mistakes and omissions were later criticized.

Some more points need stressing here:

Campaigns to produce an integrated archaeological plan were resisted by political and economic powers. Today unification proceeds through the restoration of Trajan' Market and the creation of a new cultural center ${ }^{28}$.

Comparison between the Italian and the Greek Archaeological Law shows the stronger position of Greek Ephorates in regard to Italian superintendencies, plus looser law enforcement in Italy.

The Ministero dei Beni Culturali is criticized for lack of interest in planned intervention and maintenance; free-market mentality has recently infiltrated a state-controlled system. For instance, the restoration of the Colosseum was funded by a brand name like Prada. This is avoided in the Greek archaeological system which has maintained a predominant role in every aspect of the heritage management and enhancement.

Recent research reveals that Italy and Greece have managed differently the issue of national identity in regard to classicism: In the Italian case, the redefinition of the Roman past moved from municipalism to centralism to Fascist ideology which expanded massively during the $20^{\text {th }}$ century. Presently, despite the existence of open political but also urban and aesthetic questions due to the Fascist and colonialist ideological appropriation of the Roman Empire, appropriation of Rome is not seriously probed. It is proposed that only the military character of the Roman culture should be questioned, not Rome's role towards the formation of modern Italian consciousness. This respectful attitude is occasionally less available among some specialists in, and on, Greece today [analysis in $21 ; 22$ ].

\section{Archaeological landscapes in the two cities}

Archaeological gardens, blending selected nature with refined culture, are poetic metaphors of eternity. The Renaissance explored the garden theme both in applied and in theoretical

27 One of the seven hills on which the Septimontium was celebrated.

$28 \mathrm{https} / /$ amh.de/en/ausstellungen/trajans-market-in-rome-from-ancient-monument-to-themuseum-of-the-imperial-fora/ 
manner. The former, by incorporating ancient marbles; the latter, through the theoretical elaborations of emblematic figures like Leonardo da Vinci, Petrarch and Boccaccio [17]; ruins were also introduced in landscape paintings, but enhancement through designed gardens originated as late as the Napoleonic period [32, p. 19].

Cultural loftiness is presently matched by prosaic concerns like accommodating planning and infrastructures for the tourist industry.

\section{The Athens archaeological gardens}

The past in Greek cities has not received the kind of aestheticized distance which is typical of Italian cities, according to Italian architect Franco Purini. In Athens, the materialization of a landscaped zone for the Acropolis and Philopappos Hill was commissioned to architect Dimitris Pikionis (1887-1968) in the 1950s. Pikionis' landscape (Fig. 2) was expected to facilitate tourist access, but instead offered a combined experience of pilgrimage, spiritual ascent and awareness (the prosaic-sublime dialectic here again). This project re-ignited the debates on the part of Classicism, the international place of the country, and the role of the state [16].

Architectural historian Kenneth Frampton interprets Greek architects' orchestration of architectonic space as resistance against identity dissolution [7]. Pikionis received a wide humanist education, both Eastern and Western. A sculptor of spatial, historical and emotional flows, he managed matter superbly, drawing from the spirituality of classical and Byzantine architecture, the immediate earthiness of popular architecture (possibly under the influence of Ruskin [16]), but also from Antonio Gaudi and modern artists, including Paul Klee's 1929 painting, "Main Roads and Side Roads of the Nile," his friend Giorgio de Chirico, cubist collage, plus contemporary Greek painters like his friend and intellectual companion Nikos Chadjikyriakos-Ghikas, as well as the East, especially Japan [16; 17]. Pikionis explored a participatory, somatic, culturally learned stance to posit modern Athens as seat of resistance against objectification and desacralization propelled by modernism ${ }^{29}$. Succession of views in the Acropolis landscape was calculated in both static and dynamic terms. The physical movement of the visitor introduced time, the fourth dimension, in cinematic manner, expanding and enriching cubist experiments [16; 17].

The neighbouring national garden, initially designed as palatial and botanical garden, to subsequently become a treasured public park unique in Southern Europe, is a central landscape created on the expanse of emperor Hadrian's "new," Roman Athens. It possesses a charm unmissed by local and foreign visitors alike. It is possible that its compositional principles may have inspired Pikionis. These include attention to close and remote visual targets through a number of clever tricks allowing openings towards the Attic setting, polymorphy of micro-architectures as curiosités dispersed in the garden [28], artful arrangements to increase the sense of depth and surprise through objet trouvé elements, ancient fragments found on the spot, inspiration from ideal landscapes of $17^{\text {th }}$ century French painting, subtlety, and visual links with surrounding monuments.

The arrival of the $21^{\text {st }}$ century brought the linking of the Pikionis area to a grand pedestrian zone around the Acropolis, one of the most beautiful worldwide. Unification of all major 
Athenian archaeological sites is presently underway, following recent plans. Hopefully this will include the revival of River Ilissos and its rich flora micro-environment, proposed in various plans; this is a classical locus amoenus in Plato's Phaedros, with plane trees, springs and shrines.

\section{The Rome archaeological gardens}

In Rome, the prototype for archaeological landscaping appears to be aristocratic Roman Baroque villas like Villa Borghese. Previous practices of ruins' isolation through demolitions ("clearing") have left their legacy.

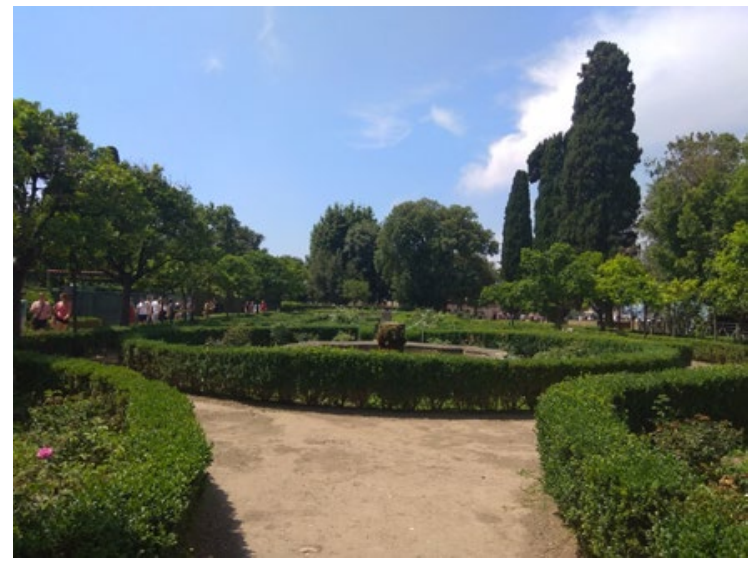

Fig. 9. An aspect from the top of Palatine Hill which overlooks the Roman Forum and the Circus Maximus.

Photo and (C) by A. Loukaki

Restoration allowed the visual and symbolic restitution of the past. Both demolitions and restorations of ancient strata were in attendance before the relevant Italian and European restoration theory was fully developed [16]. While contemporary purism drastically dictated the riddance of sites from urban stratigraphies considered secondary, quiet symmetry followed, and still follows traditional principles ${ }^{30}$ in an embellishing spirit (Fig. 9) to promote a neutral aesthetic neatness and a purifying attitude. While pleasing, this attitude diminishes or circumvents existential confrontation with the past, both ancient and recent. Besides, though it is commendable that ongoing works in the archaeological center modernize its infrastructure, they do not appear to circumvent the political and social challenge posed by the very existence of the Via dei Fori Imperiali, as the Archaeological Service still remains weaker than local conservative powers.

\section{The next steps ahead}

The question posed now is: What can we infer from this fundamental comparison between classical Athens and eternal Rome? The preceding discussion revealed, I hope, that major cultural icons can trigger new rounds of creativity but also struggles over representation, social, artistic, national and international. What appears vital is loyalty to the historical significance and capacity of these archetypes to strengthen individuals as well as societies come what may $[10 ; 16]$.

To intervene in the material conditions or symbolic interpretations of monuments such as the Athenian Acropolis or the Roman Forum equates no less than to intervene in the selfunderstanding and self-respect of a city and people. as an apparently direct transcription of nature [18], facilitating the spread of aesthetic conventions. Aligned cypresses are wonderful in the Tivoli landscape, though, as the immensity of Hadrian's villa profits from clear perspectives. 
However, the analysis also indicates that certain kinds of urban interventions to reinterpret and incorporate the past, such as the design of archaeological landscapes, can propel the collective empowerment, consciousness, and prospect. Such urban projects are created by brilliant artistic and cultural translators inspired by universal as well as by local, communal and democratic insights.

\section{References}

1. Agnew J. Rome. Chichester, West Sussex, John Wiley Publ., 1995. $189+$ xiv p.

2. Benjamin A. Working with Walter Benjamin: Recovering a Political Philosophy. Edinburgh, Edinburgh University Press Publ., 2013. 272 p.

3. Bourdieu P. Le Sens Pratique. Paris, Editions de Minuit Publ., 1980. 480 p. (in French).

4. Coetzee J. M. The Man Who Went Shopping for Truth, 2001. Available at: https://www.theguardian. com/books/2001/jan/20/history.society (accessed 1 May 2019).

5. de Lillo D. The Names. New York, Vintage Publ., 1982. 352 p.

6. Foster B.; Marcovitz H. Rome, with introduction by Harold Bloom. New York, Chelsea House Publ., 2005. 197 p.

7. Frampton K. A Note on Greek Architecture: 1938-1997. Aisopos Y.; Simeoforides G. (eds.). Landscapes of Modernization - Greek Architecture in the 1960s and 1990s. Athens, Metapolis Publ., 2002. 144 p. (in Greek).

8. Gammon M. Modernity and the Crisis of Aesthetic Representation in Hegel's Early Writings. Maker W. (ed.). Hegel and Aesthetics. New York, State University of New York Publ., 2000, pp. 145-160.

9. Giustozzi N. The Colosseum Book. Milan, Electa Publ., 2017. 256 p.

10. Harvey D. Justice, Nature, and the Geography of Difference. Oxford, Blackwell Publ., 1996. 480 p.

11. Herzfeld M. Evicted From Eternity - The Restructuring of Modern Rome. Chicago, University of Chicago Press Publ., 2009. 392 p.

12. Kirk T. R. The Political Topography of Modern Rome, 1870-1936. Via XX Settembre to Via dell Impero. Caldwell D.; Caldwell L. (eds.). Continuing Encounters between Past and Present, London, Routledge Publ., 2011, pp. 101-128.

13. Le Corbusier. Towards a New Architecture. London, The Architectural Press Publ., 1974. 312 p.

14. Lord Byron 1812-1818. Childe Harold's Pilgrimage. Available at: https://www.gutenberg.org/ files/5131/5131-h/5131-h.htm (accessed 1 May 2019).

15. Loukaki A. Greece: Ancient Ruinous Landscapes, Aesthetic Identity, and Issues of Development. Dialogues d'Histoire Ancienne, 2004, no. 30 (1), pp. 147-164.

16. Loukaki A. Living Ruins, Value Conflicts. Aldershot, Ashgate; London, Routledge Publ., 2008-2016. 360 + x p.

17. Loukaki A. The Geographical Unconscious. Aldershot, Ashgate; London, Routledge Publ., 2014-2016. 415 + xvi p.

18. Loukaki A. Central Archaeological Domains of Athens and Rome: Physical, Metaphysical and Moral Aspects of their Respective Management. Moraitis K.; Rassia St. (eds.). Urban Ethics under Conditions of Crisis. Politics, Architecture, Landscape Sustainability and Multidisciplinary Engineering. Singapore, World Scientific Publ., 2019, pp. 81-114.

19. Loukaki A. Introduction. Loukaki A. (ed.). Urban Art and the City. Creating, Destroying, and Reclaiming the Sublime. London, Routledge Publ., 2020.

20. Loukaki A. Desacralized Eleusis. Contemplating the Impacts of Non-Restoration on a Major Classical and Poetic Locus. Athens University Review of Archaeology (AURA), forthcoming 1.

21. Loukaki A. Art and National Consciousness: The Issue of Continuity and the Importance of Greek Permanencies. Loukaki A. (ed.) Art - Architecture - Urban Planning in Greek Antiquity. Patras, Hellenic Open University Publ., forthcoming 2.

22. Loukaki A. The Italian Appropriation of the Roman Empire. Loukaki A. (ed.). Art - Architecture - Urban Planning in Greek Antiquity. Patras, Hellenic Open University Publ., forthcoming 3.

23. Lyons C. L.; Papadopoulos J. K.; Stewart L. S.; Szegedy-Maszak A. Antiquity Photography -Early Views of Ancient Mediterranean Times. London, Thames \& Hudson Publ., 2005. 246 p.

24. Malnar J. M.; Vodvarka F. Sensory Design. Minnesota, University of Minnesota Press Publ., 2004. 376 p.

25. Manacorda D. Archaeology and the Modern City: Thoughts on Rome (and Elsewhere). Caldwell D.; Caldwell L. (eds.). Rome - Continuing Encounters Between Past and Present. London, Routledge Publ., 2011, pp. 207-219. 
26. Matteini T. Paesaggi del Tempo: Documenti Archeologici e Rovine Artificiali nel Disegno. Florence, Alinea Publ., 2009. 176 p. (in Italian).

27. Moullas P.; Mentzou V. Pages for Greece of the $20^{\text {th }}$ Century: Texts of French Visitors. Athens, Olkos Publ., 1995. 350 p. (in Greek).

28. Papageorgiou-Venetas A. The Garden of Amelia - Design, Foundation and Evolution of the National Garden of Athens. Athens, Ikaros Publ., 2007. 262 p. (in Greek).

29. Pérez-Gómez A.; Pelletier L. Architectural Representation and the Perspective Hinge. Cambridge, Massachusetts, The MIT Press Publ., 1997. 526 p.

30. Purcell N. The City of Rome. Jenkyns R. (ed.). The Legacy of Rome - A New Appraisal. Oxford, Oxford University Press Publ., 1992, pp. 421-453.

31. Purini F. Sette paesaggi / Seven Landscapes. Milan, Mondadori Electa Publ., 1989. 136 p.

32. Rossi A. The Architecture of the City. Cambridge, Massachusetts, The MIT Press Publ., 1982. 208 p.

33. Scully V. The Earth, the Temple and the Gods. New Haven, Connecticut, Yale University Press Publ., 1979. 303 p.

34. Smith G.; Gadeyne J. (eds.). Perspectives on Public Space in Rome, from Antiquity to the Present Day. London, Routledge Publ., 2013. 434 p.

35. Springer C. The Marble Wilderness: Ruins and Representation in Italian Romanticism, 1775-1850. Cambridge, Cambridge University Press Publ., 2010. 210 p.

36. Wordsworth Ch. Athens - Attica - Journal of a Residence There. Athens, Hekate Publ., 1999. 296 p. (in Greek).

Title. Athens and Rome Contrasted: The Present Challenge of Managing Two Manners of Classicism

Author. Loukaki, Argyro - D. Phil. Oxon., professor, director of program in Greek Civilization and Culture. Hellenic Open University, Aristotelous 18, Patras 263 35, Greece. Argyro-loukaki@hotmail.com; aloukaki@eap.gr

Abstract. The main contribution of the present article is the original comparison of the archetypal yet different classicisms of Athens and Rome, with emphasis on the physical, metaphysical, aesthetic and moral aspects of the management of their central archaeological loci. Athens and Rome are the two preeminent classical cities globally. Their world heritage has been nurturing for centuries global collective memory, creativity, inspiration, and myth. The Sacred Rock of the Athenian Acropolis is the epitome of democracy, classical beauty and urban constitution; the Acropolis spatialities are a form of vital energy. The Roman Forum, alongside the neighboring Colosseum, joins and represents imperial power, structural prowess and prominent urbanism. Enduring through tests of time, iconic classical ruins stage modern urban action, real and symbolic. They recapitulate cities as syntactic urban permanences, trigger new creativity, and loom in struggles over national and global representation - indicatively, following the "fever for marble," classical ruins involuntarily supplied museum collections with architectural members and statues -, plus artistic relevance and progress.

With regard to the planning-preservation interface, major archaeological urban landscapes like the Acropolis and the Forum-Colosseum pair are usually involved in six distinct processes. First, their unearthing usually demands planned excavation expeditions. Second, subject to various preservation regulations, the new development around them may be completely stopped or highly controlled with the effect that urban density is drastically lowered. Third, they may undergo restoration, a demanding and time-consuming process which radically alters their public presence. Fourth, they may be accompanied by museums specifically built in their vicinity, like it happens in this case with the New Acropolis Museum. Fifth, they are usually linked to the surrounding urban space, and sometimes to other archaeological sites, via landscaped gardens and pedestrian zones functioning as transitional areas or corridors. Sixth, they may necessitate protection from environmental pollution, infrastructural works or other sources of deterioration.

The points addressed by the article are the prosaic and sublime aspects of classicism(s) plus similarities and differences between Athens and Rome. Their archaeological cores inspire creative imagination in architectural, artistic, aesthetic and literary terms. More specifically, in this article are discussed: the Greek archaeological context in conjunction with a number of important issues; the Italian archaeological and political context before and after Fascism, in parallel with the Roman past and ruins; the formation of the Athenian archaeological landscape in the 1950s as a major accomplishment of architect Dimitris Pikionis; the present Roman archaeological landscape, compared with Pikionis. Further, aesthetic notions like the urban uncanny and urban lightness/luminosity are substantiated around Roman and Athenian classicism respectively.

Keywords: Athens and Rome, symbolic and material sources of classicism, dimensions of archaeological management, prosaic and sublime aspects of classicism, archaeology, national and global representation, Athenian and Roman classicism, cinema, literature, classicism and transcendence, political abuses in the 
name of classicism, optimal and neutral archaeological landscaping, architect Dimitris Pikionis, Acropolis landscape, urban uncanny opposed to urban luminous

Название статьи. Афины и Рим: современные вызовы администрированию форпостов классицизма

Сведения об авторе. Лукаки Аргиро - Ph. D., профессор, директор программы «Греческая цивилизация и культура». Греческий открытый университет, ул. Аристотеля 18, Патрас 263 35, Греция. argyro-loukaki@hotmail.com; aloukaki@eap.gr

Аннотация. Научная новизна статьи состоит в оригинальном сравнении архетипических и тем не менее различных форм афинского и римского классицизма с акцентом на физические, метафизические, эстетические и моральные аспекты, связанные с управлением названными центральными археологическими локусами. В широком смысле Афины и Рим - выдающиеся столицы Классики и классицизма. Их мировое наследие веками питает коллективную память человечества, становится основой творчества, вдохновения и мифосложения. Священная скала Афинского Акрополя - символ демократии, классической красоты и городского права. Архитектоника Акрополя является формой витальной энергии. Римский Форум, наряду с соседствующим Колизеем, конвергирует имперскую власть, мастерство и смелость структурного планирования, а также является примером выдающейся урбанистической идеи. Испытанные временем, культовые классические руины задают тон современной градостроительной деятельности, как непосредственной, так и символической; резюмируют идею современных городских пространств как синтаксических урбанистических постоянств; служат триггером для раскрытия нового творческого потенциала; дают о себе знать в борьбе за глобальную и национальную репрезентацию. Недаром вслед за «мраморной лихорадкой» классические руины не только обогатили музейные собрания архитектурными экспонатами и статуями, но придали им художественную значимость и послужили толчком для научного прогресса.

Проблема изучения, хранения и консервации основных архитектурно-археологических памятников Акрополя и пары Форум-Колизей ставит перед нами шесть значимых аспектов. Во-первых, для осуществления раскопок на указанных территориях требуется организация чётко спланированных археологических экспедиций. Во-вторых, при условии комплексного соблюдения правил консервации ведение новой застройки вокруг рассматриваемых памятников может быть полностью прекращено или подвергнуто жёсткому административному контролю, что приведёт к резкому снижению плотности городского населения. В-третьих, сами памятники могут быть подвергнуты восстановлению, сложному и трудоёмкому процессу, который радикально меняет их общественное значение, их роль в создании и реконструкции той среды, в которую они вписаны. В-четвёртых, реставрация памятников может сопровождаться организацией музеев, специально построенных в непосредственной к ним близости (как это происходит ныне с Новым музеем Акрополя). В-пятых, обычно подобные памятники тесно связаны с окружающим городским пространством, а иногда и с другими археологическими объектами. Связующим звеном часто служат ландшафтные сады и пешеходные зоны, выступающие в качестве переходов или коридоров. В-шестых, такие архитектурные сооружения требуют защиты от загрязнённой окружающей среды, инфраструктурных работ или других источников порчи.

Затрагиваемые в статье проблемы касаются не только решений прозаических практических задач. Автор видит свою цель в том числе в рассмотрении возвышенных аспектов классицизма(-ов), а также сходств и различий между Афинами и Римом. Археологические центры этих городов будоражат творческое воображение в архитектурном, художественном, эстетическом и литературном плане. В подтверждение сказанного автор касается таких вопросов, как: греческий археологический контекст и его связь с важнейшими проблемами; итальянский археологический и политический контекст до и после фашизма; формирование афинского археологического ландшафта в 1950-е гг. как главное достижение архитектора Димитриса Пикиониса; сравнение современного римского археологического ландшафта с тем, что был сформирован усилиями Пикиониса. Также вводимые противоположные эстетические представления «урбанистическая сверхъестественность» (urban uncanny) и «урбанистическая лучезарность» (urban lightness/luminosity) применяются к римской и афинской классике соответственно.

Ключевые слова: Афины и Рим, символические и материальные источники классицизма, компетенции археологического управления, прозаические и возвышенные аспекты классицизма, археология, национальная и мировая репрезентация, афинский и римский классицизм, кино, литература, классицизм и трансцендентность, политические злоупотребления классицизмом; оптимальный и нейтральный археологический ландшафт, архитектор Димитрис Пикионис, ландшафт Акрополя, урбанистическая сверхъестественность, урбанистическая лучезарность 